\title{
Bile Duct Tissue
}

National Cancer Institute

\section{Source}

National Cancer Institute. Bile Duct Tissue. NCI Thesaurus. Code C43615.

The tissue that forms the bile duct wall. It is lined by epithelium. 